ISSN: 2716-1277 e-ISSN: 2716-1269

Available online at TIIChttps://jlic.iain-jember.ac.id/
Journal of Language Intelligence and Culture

Fakultas Tarbiyah dan Ilmu Keguruan

IAIN Jember

Vol. 2, No.2, Page 141-158, December 2020

\title{
Illocutionary Act in Political Debate
}

\author{
Siti Khodijah, \\ IAIN Jember \\ sikodsiti@gmail.com
}

\section{ARTICLE INFO}

Article History:

Accepted: November, $19^{\text {th }} 2020$

Approved: December, 27th 2020

Published: December 2020

Key Words:

Speech act, Illocutionary act, Political debate

DOI: $10.35719 / j$ lic.v2i2.39

\begin{abstract}
This study analyzes illocutionary act in political debate that was conducted by general election commision on March, 30 2019. This debate was about ideology, government, security and defense, and international relationship. In this research, Searle's theory was used who classified five types of illocutionary act; representative, directive, commisive, expressive, and declarative. This research used descriptive qualitative. The main focus of this study is to get deep understanding and interpretation how the politicians argue each other using illocutionary act. The results of this study suggested that both of the candidates of president did not use all of the illocutionary act types proposed by Searle. The three illocutionary acts used by both of the candidates are, representative, directive, commissive. Meanwhile, another type of illocutionary acts used by one of the candidates is declarative, while another one used expressive.
\end{abstract}

\section{INTRODUCTION}

Debate is one of the activity that contains of two people or two groups in argued something. Based on Oxford dictionary (http://en.oxforddictionaries.com), debate (n) is a formal discussion on a particular matter in a public meeting or legislative assembly, in which opposing arguments are put forward and which usually ends with a vote. Debate (v) is an argue about ( a subject), especilly in a formal manner. Related to the definition above, Indonesia has conducted debate of president and vice president for several times. Since, in this year, Indonesia has a big party, that is 


\section{JLIC}

democration party. This event was held on April 17th, 2019. It is a must for all of Indonesian to join and choose the candidate of president, vice of president, and legislative candidate, whether regency, province, or national legislative candidate. Every candidat, they have to declare their vision or mission to the citizen through media, such as electronic media, print out media, or social media, in order that the citizen know their vision and mission. Moreover, for the candidates of president and his vice president, they have to attend debate which is conducted by general election commision (KPU) in electronic media live. In this event, they have to convince their partisan by using strong arguments. In producing their arguments, they use the words that have certain meaning to influence the society in againts debate, they have to be strengthen their words in order the citizen understand well what they said. Further, they have to say it clearly in order that there is no misunderstanding in producing some argument. Yet, in several arguments, the candidate of president used illocutionary acts when they produced the utterance.

Illocutionary is one of types of speech act. Speech act as the actions performed in saying something (Austin, 1962). In speech act, people is not only producing the utterance that contains grammatical structure and words, but also they are performing the actions by the uttarances (Yule, 1996). It means that the speaker do not only deliver a message but also they create a social relation with the listener. Yule (1996) divided speech act into three types. They are locutionary, illocutionary, and perlocutionary act.

Locutionary act is the basic act utterance or producing a meaningful linguistic expression. It is an act of saying something in literal meaning, or it can be said that this act is the utterance that has textual meaning (Yule, 1996). Then, there is no certain meaning in the utterance that is produced by the speaker. For example "my mother asked me to buy some food". From that utterance, it is clearly stated that a mother asked his son to buy some food. It does not need to interpret it, since that sentence is understandable and has truth value.

While illocutionary act is when someone says something, he/she produces that utterance with no purpose, but he/she produces the utterance with some kind of social function in the mind. Moreover, Abdul Chaer (2004) stated that this act related to the intended meaning. It means that, in uttering some words or 
sentences, the speaker has certain meaning to the listener. For example "It's so hot". There are many interpretations from that sentence. In illocutionary act, it can be intrepreted as the speaker asked someone to open the window, or give an ice, or turn on the fan.

The last type is perlocutionary act. It is assumption that the hearer will recognize the effect of speaker intended. In this act, the hearer will do what the speakers said. It is the action or the effect of the hearer from the speakers said. For example from the utterance above, the hearer directly opens the window, or give an ice, or turn the fan. That action indicates that the perlocution is occurs, since the listener understand with the illocutionary of the utterance. The communication is reached when the hearer understand what the speaker said.

In understanding the utterances is not enough with the literal meaning, but it needs to know the intended meaning behind those. Therefore, illocutionary is needed to be studied, since this act as the main central of communication. Gunarwan (2007:7) stated that illocutionary act is the basic of analysis in pragmatics. Pragmatics is concerned with the study of meaning which is produced by the speaker and it is interpreted by the hearer (Yule, 1996:3). Therefore, the hearer knows the purpose of the speaker by understanding the illocutionary act that is delivered by the speaker. Searle (1976:10) mentioned five classifications of illocutionary act, they are representative, directive, commisive, expressive and declarative. Yet, ecah of them has different meaning and context.

Representative means that the speaker believes something to be the case or not. Leech (1983:105) proposed the examples of this act, such as stating, suggesting, boasting, complaining, claiming, and reporting. In producing a representative, the speaker conveys his/her belief that some proposition is true. In other words, the words that are used by the speaker, state what the speaker believes to be the case, such as describing, claiming, hypothesizing, insisting and predicting (cutting, 2008:14). While Searle in Yule (1996:53) described representative to many types, as stating, denying, admitting, asserting, confessing,notifying, predicting.

Directive means that when the speaker requests to the listener, he/she performs an action. By uttering the directive, the speaker tries to get the listener to do something. This act represents what the speaker wants. When the speaker orders, commands, 


\section{JLIC}

requests, advises, asks, begs, bids, demands, forbids, and recommends actually he/she tries to get the listener to carry out some actions. While commisive is asking the speaker to do something in the future. By producing commisive, the speaker commits himself/herself to some future action, as promise, vow, offer, volunteer, guarantee, pledge, and bet. Expressive that is showing an expression how the speaker feels about the situation. This act expresses a psychological state. Its function is to express or to know about the speaker's psychological attitude towards a state of affairs which the illocution presupposes. The last is declarative. It changes the world by the utterance which is produced (Searle in Yule, 1996:53). When the speaker produced a declaration, his or her words bring about a new state of affair. By producing some sentences, it can change the status of a person or the ownership of something.

Related to the definiton above, this research conducted llocutionary act that is used by the candidates of president in their debate. Forth debate was taken as my subject, since this debate is about ideology, safety goverment, administration, and international relation. From this debate the audience knows how theirthought of each candidate. They argues each other by using their words which were influenced by their ideology. Hence, this research is interesting to be conducted.

Related to this research, there are some previous studies which relate to this reserach. Rijal S (2016) focused on Illocutionary and Perlocutionary Act on Madurese Language. His finding shows that people in Madura used direct and indirect speech to express what they want. They used locutionary and perlocutionary in their conversation that intends to refuse, threaten, order, forbid, motivate and ask. Widiatmoko P (2017) focused on analysis of presidential inaugural addresses using Searle's taxonomy of speech act. His finding shows that each of inaugural address possessed distinctive characteristics influenced by sociopolitical, economic, and historical ssituation of the countries. Mufiah, dkk (2018) shows their finding that Donald Trump asserts to the audience about the nation will be. Trump's speech acts are intended as statement of fact and assertion. Hajan, B. dkk (2018) focused on A Speech Act Analysis of the Last Two Post-Martial Law Philippine Presidents' First State of the Nation Addresses. Their finding shows that demonstration of utmost power and authority remains as a core 
quality of presidential speeches. Presidents used assertive to establish authority and supremacy.

\section{METHODS}

This research is descriptive qualitative. Descriptive, means that this research is describing the words or utterances that is produced by all of the candidate of president. In this research, I describe the utterance in detail description that contains illocutionary. In addition, this reserach is categorical as qualitative, since this research is to get deep understanding and interpretation how they argued each other using illocutionary act. Moreover, this research uses human as the main instrument. Therefore, this research is classified as descriptive qualitative. The data of this research is in the forms of utterances that are produced by two candidates. The data source of this study is a transcription of debate. The study focused on the illocutionary act that is used by the candidates in the fourth debate.

\section{RESULTS AND DISCUSSION}

\section{Results}

The results of the study can be seen in the following chart:

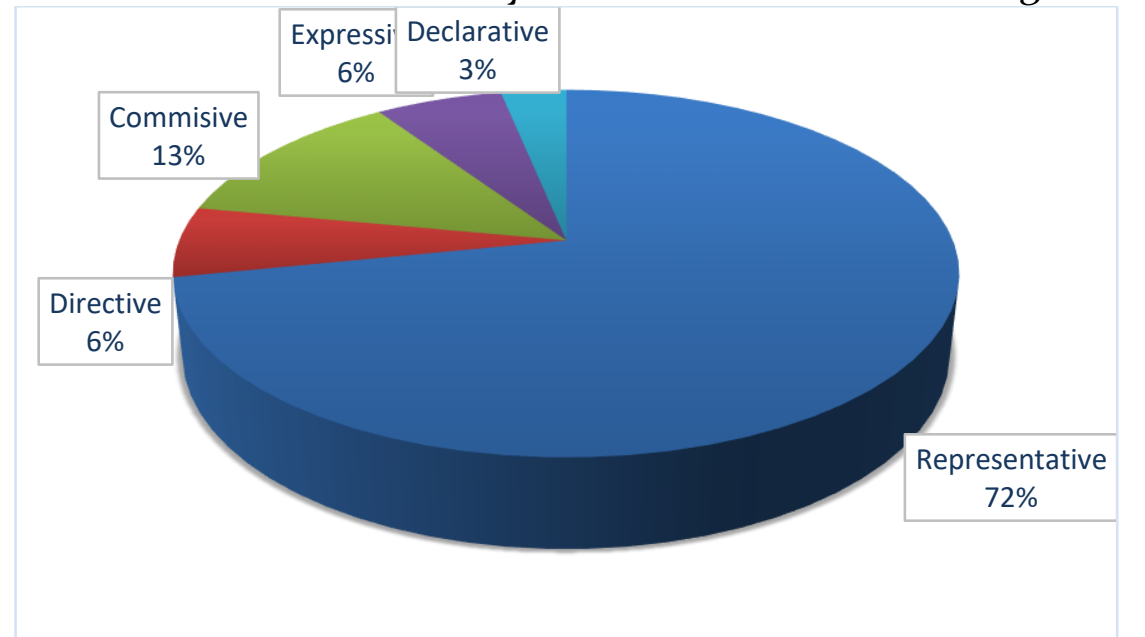

Chart 1. The Percentage of Illocutionary Acts within the Collected Data

There are thirty-two (32) utterances collected from the political debate's transcript. These utterances are then analyzed. From Chart 1, it can be seen that the dominant illocutionary acts 


\section{JLIC \\ Journal of Language Intelegence and Culture}

performed by candidates were representative with the percentage of $72 \%$. Meanwhile, commisive type of illocutionary acts got the percentage of $13 \%$. On the other hand, both directive and expressive type of illocutionary acts got the same percentage with $6 \%$ and the candidates only performed declarative type of illocutionary acts by the percentage of $3 \%$. Therefore, from the result, it can be said that the candidates focus more on stating their believes and giving any appropriate response in the form of denying or admitting to the discussed matter.

\section{Discussion}

Based on Searle's theory, five types of illocutionary act in the forth of presidential debate has been identifed. The data was taken on 3oth April 2019. http://Transkrip Lengkap Visi-Misi Jokowi dan Prabowo di Debat Keempat - kumparan.com.html

1. Representative

\begin{tabular}{|c|c|c|c|}
\hline No & Statement & $\begin{array}{l}\text { Type of } \\
\text { illocutionary }\end{array}$ & Speaker \\
\hline 1 & $\begin{array}{l}\text { Hari ini kita akan bicara tentang } \\
\text { ideologi pemerintahan, } \\
\text { pertahanan, keamanan, dan } \\
\text { hubungan internasional. } \\
\text { Saudara saudara bagi kami } \\
\text { Pancasila adalah ideologi final, } \\
\text { Pancasila adalah hasil suatu } \\
\text { kompromi besar suatu } \\
\text { kecemerlangan dari generasi } \\
\text { pendiri bangsa kita. } \\
\text { (Today, we will talk about the } \\
\text { ideology of governance, defense, } \\
\text { security and international } \\
\text { relations. Brothers and sisters. } \\
\text { For us, Pancasila is the final } \\
\text { ideology. Pancasila is the result } \\
\text { of a great compromise of the } \\
\text { brilliance of our nation's } \\
\text { founding generations) }\end{array}$ & $\begin{array}{l}\text { Representative } \\
\text { (Statement of } \\
\text { fact) }\end{array}$ & Prabowo \\
\hline 2 & $\begin{array}{lr}\text { Pancasila } & \text { berhasil } \\
\text { mempersatukan } & \text { ratusan } \\
\text { kelompok etnis, ratusan suku, } \\
\text { agama-agama besar, budaya- } \\
\text { budaya berlainan, dengan } \\
\text { bahasa yang } \\
\begin{array}{l}\text { kompromi berlainan, } \\
\text { ini }\end{array}\end{array}$ & $\begin{array}{l}\text { Representative } \\
\text { (statement of } \\
\text { fact) }\end{array}$ & Prabowo \\
\hline
\end{tabular}




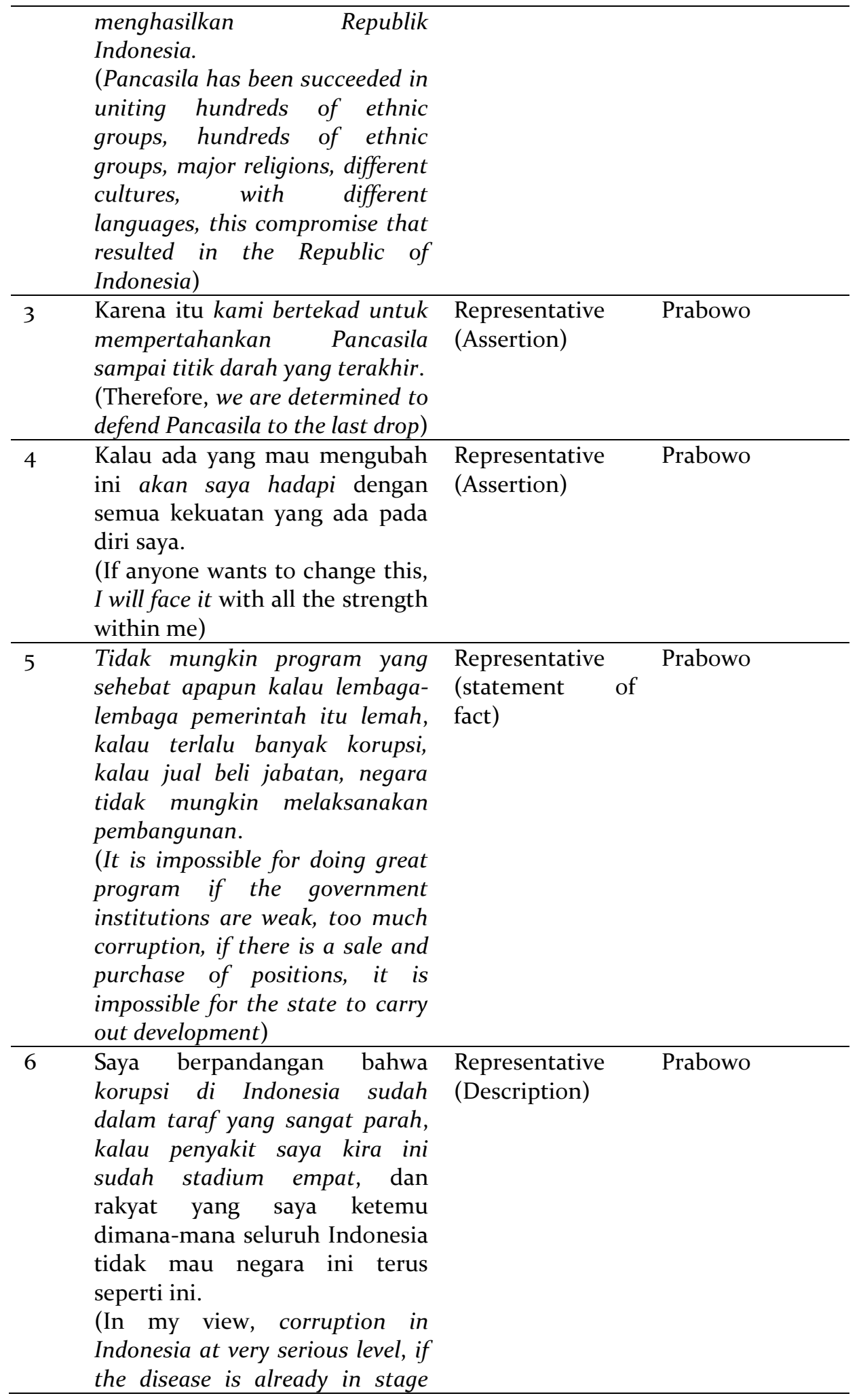




\section{JLIC \\ Journal of Language Intelegence and Culture}

four, and the people I meet everywhere throughout Indonesia do not want this country to continue like this)

\begin{tabular}{l} 
Mereka ingin negara dengan Representative Prabowo \\
pemerintahan yang tidak korup. (statement of \\
(They want a country with a fact) \\
government that is not corrupt) \\
Pancasila adalah kesepakatan Representative Joko Widodo \\
para pendiri bangsa para (statement of \\
pemimpin-pemimpin bangsa dari fact) \\
berbagai daerah berbagai \\
organisasi berbagai ras berbagai \\
suku berbagai agama saat itu. \\
Oleh sebab itu, menjadi \\
kewajiban kita bersama untuk \\
menjaga, merawat, dan \\
menjalankan Pancasila dalam \\
kehidupan sehari-hari dalam \\
berbangsa dan bernegara. \\
(Pancasila is the agreement of \\
the founders of the nation, the \\
leaders of the nation from \\
various regions of various \\
organizations of various races, \\
various ethnic groups of various \\
religions at that time. Therefore, \\
it is our collective obligation to \\
maintain, care for and carry out \\
Pancasila in everyday life in the \\
nation and state) \\
Di bidang pemerintahan ke Representative \\
depan diperlukan pemerintahan (Assertion) \\
dilan (digital melayani). Oleh \\
sebab itu, diperlukan reformasi \\
dalam pelayanan publik lewat \\
elektronik, yang kedua \\
diperlukan penajaman dan \\
penyederhanaan kelembagaan, \\
yang ketiga diperlukan \\
peningkatan kualitas SDM \\
(sumber daya manusia) aparatur \\
kita dan yang empat diperlukan \\
reformasitata kelola. \\
(In the field of government in the \\
future, dilan (digital serving) \\
government is needed. Therefore, \\
reforms in public services via \\
\hline 9
\end{tabular}




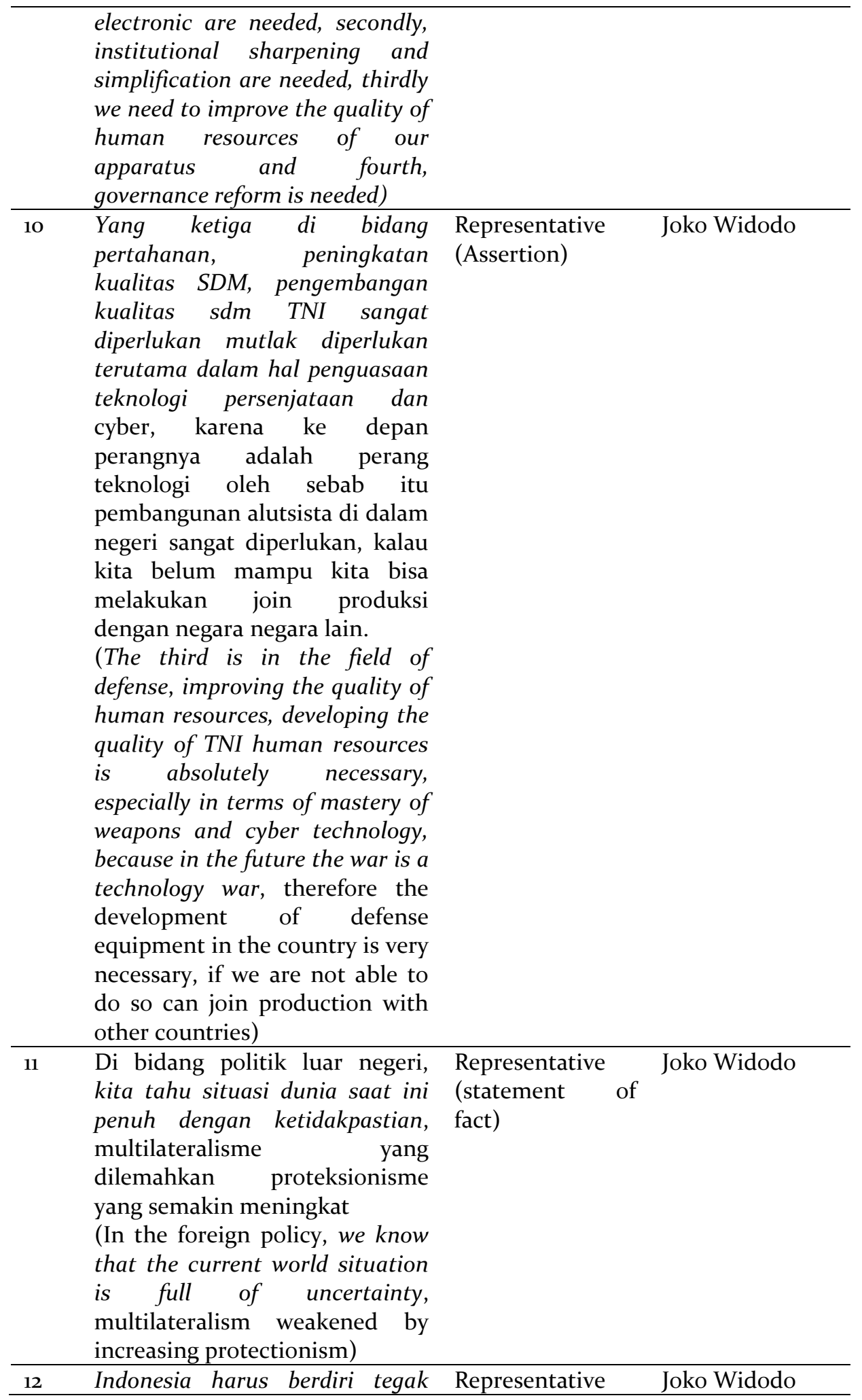




\section{JLIC \\ Journal of Language Intelegence and Culture}

bermartabat dan tetap (Assertion)

menjalankan politik luar negeri

yang bebas aktif, bebas, bebas

menjalankan memperjuangkan

kepentingan kepentingan

nasional dan aktif dalam ikut

dalam perdamaian dunia yang

baik.

(Indonesia must stand upright with dignity and continue to carry out a foreign policy that is free, active, free, free to fight for the interests of national interests and actively participate in good world peace)

13 Apa yang kita harapkan dari gelar pasukan ini, artinya titiktitik pinggir yang ada di negara ini semuanya terjaga dan juga perlu saya sampai sampaikan bahwa, yang namanya radar maritim kita radar udara kita ini sudah menguasai seluruh wilayah kita $100 \%$, karena ada 19 titik radar udara kita yang telah terkoneksi. Ada 11

radar maritim kita yang telah tersambung dan terkoneksi.

(What we expect from the title of this troop, it means that the edge points in this country are all preserved and $I$ also need to say that, our maritime radar, our air radar, has controlled all of our territory $100 \%$, because there are 19 points. our connected aerial radar. There are 11

our connected and connected maritime radar)

14 Sebagai pemimpin saya optimis dengan penguasaan radar udara, radar maritim yang seratus Representative Joko Widodo (Assertion)

persen dan siapapun yang masuk ke teritori kita akan ketahuan, akan ketahuan.

(As a leader, I am optimistic that the mastery of air radar, 
maritime radar is one hundred percent and anyone who enters our territory will be caught, will be caught)

\begin{tabular}{l} 
Kita sudah telah memiliki tank Representative \\
harimau. Kita juga telah (statement of Joko Widodo \\
memiliki kapal selam hasil fact) \\
kerjasama kita dengan negara \\
lain, yang namanya kapal selam \\
dadali karena kita belum siap \\
untuk mengerjakan itu. Kalau \\
investasi-investasi di bidang \\
pertahanan itu terus dilakukan. \\
Saya yakin kita akan memiliki \\
alutsista yang baik, tapi kita juga \\
memiliki teknologi, menguasai \\
teknologi dan bisa transfer of \\
knowledge dari yang sudah \\
memiliki teknologi, itu. \\
(We already have a tiger tank. \\
We also have a submarine from \\
our cooperation with other \\
countries, which is called the \\
dadali submarine because we are \\
not ready to do that. If the \\
investments in the defense \\
sector continue. I am sure we \\
will have good defense \\
equipment, but we also have \\
technology, master technology \\
that can transfer knowledge \\
from those who already have \\
technology, that is) \\
Negara kita Indonesia adalah Representative \\
negara dengan penduduk muslim (statement of \\
terbesar di dunia. \\
(Indonesia is a largest Muslim \\
population in the world) \\
Saya kira itulah kekuatan Representative \\
diplomasi kita di dalam forum- (Description) \\
forum internasional, oleh sebab \\
itu di dalam forum-forum \\
internasional selalu saya \\
sampaikan di awal, bahwa \\
Indonesia adalah negara dengan \\
penduduk muslim terbesar di \\
dunia, karena banyak negara \\
lain yang belum tahu mengenai \\
\hline 17 \\
\end{tabular}




\section{JLIC \\ Journal of Language Intelegence and Culture}

posisi kita seperti itu, dan diplomasi ini kita sekarang ini diberikan kepercayaan untuk menyelesaikan banyak hal yang berkaitan dengan konflik dan perang yang ada.

(I think that is the strength of our diplomacy in international forums, therefore I always convey in international forums that Indonesia is a country with the largest Muslim population in the world, because many other countries do not know our position, such as that, and in this diplomacy we are now given the confidence to solve many things related to the existing conflicts and wars)

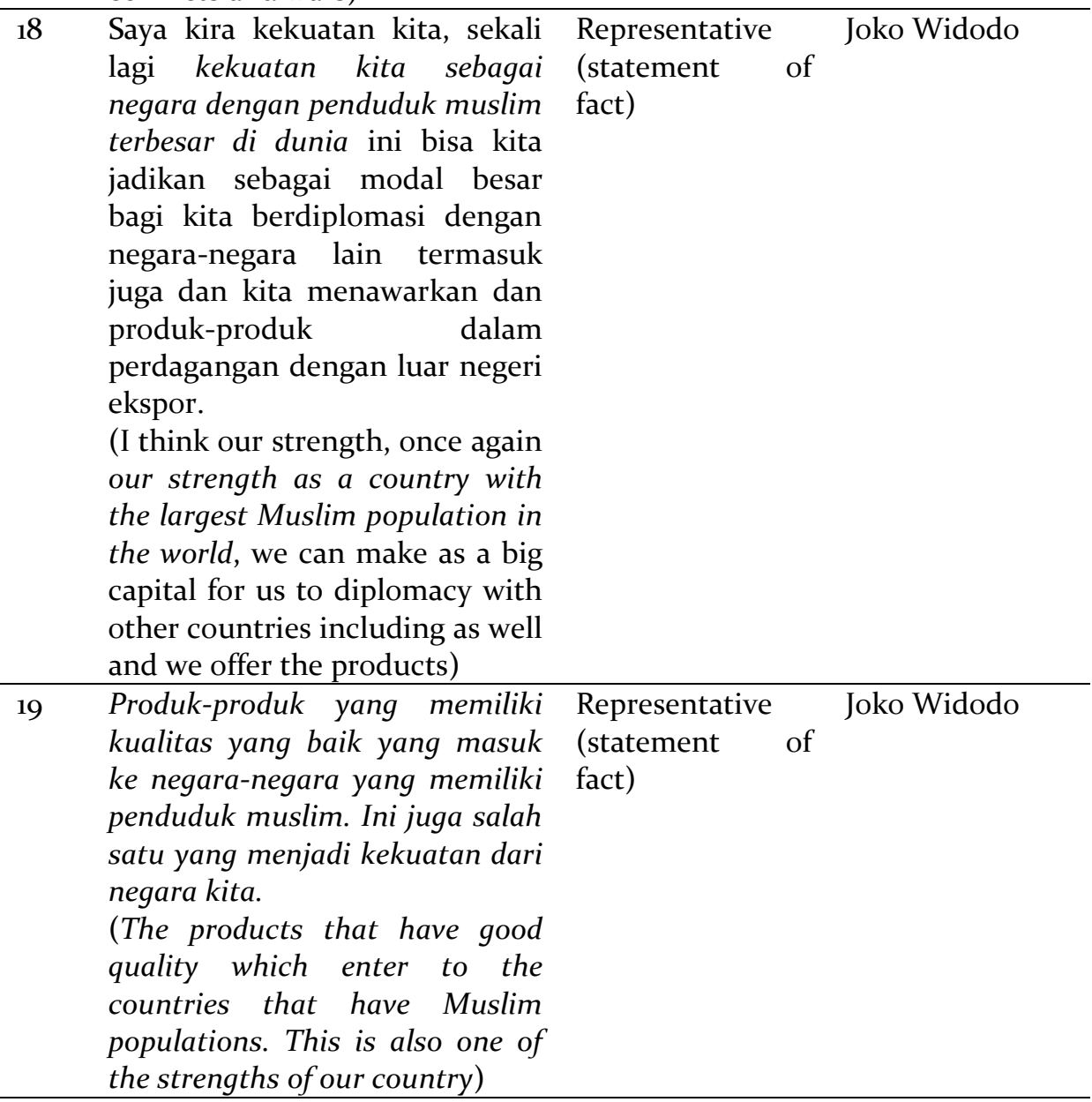




\begin{tabular}{|c|c|c|c|}
\hline 20 & $\begin{array}{l}\text { Kita juga memiliki diplomat- } \\
\text { diplomat yang sangat pintar } \\
\text { dalam menyelesaikan masalah- } \\
\text { masalah yang berkaitan dengan } \\
\text { perjanjian itu dan SEPA dan spot } \\
\text { yang lebih luas untuk investasi } \\
\text { dan perdagangan kita juga telah } \\
\text { bertanda-tangan dengan } \\
\text { Australia, dengan catatan } \\
\text { product-product kita nanti bisa } \\
\text { masuk ke sana. } \\
\text { (We also have diplomats who are } \\
\text { very smart in solving problems } \\
\text { related to the agreement and } \\
\text { SEPA and a wider spot for } \\
\text { investment and trade. We have } \\
\text { also signed with Australia, } \\
\text { provided that our products will } \\
\text { be there) }\end{array}$ & $\begin{array}{l}\text { Representative } \\
\text { (statement of } \\
\text { fact) }\end{array}$ & Joko Widodo \\
\hline 21 & $\begin{array}{l}\text { Saya sekali lagi, saya ingin } \\
\text { menggarisbawahi bahwa } \\
\text { penguatan pengembangan SDM } \\
\text { (Sumber Daya Manusia) TNI } \\
\text { terutama dalam penguasaan } \\
\text { teknologi persenjataan dan } \\
\text { cyber sangat diperlukan dalam } \\
\text { pertahanan negara kita ini ke } \\
\text { depan, ini kuncinya di sini } \\
\text { mengenai pembelian pembelian } \\
\text { hal-hal yang sangat teknis itu } \\
\text { saya kira TNI lebih tahu. } \\
\text { (Once again, I want to underline } \\
\text { that strengthening of the } \\
\text { development human resources } \\
\text { of TNI, especially in mastery of } \\
\text { weapon and cyber technology is } \\
\text { very needed in the defense of } \\
\text { our country in the future, this is } \\
\text { the key for regarding the } \\
\text { purchase of very technical } \\
\text { things. I think The TNI knows } \\
\text { better) }\end{array}$ & $\begin{array}{l}\text { Representative } \\
\text { (Assertion) }\end{array}$ & Joko Widodo \\
\hline 22 & $\begin{array}{l}\text { Dan perlu saya sampaikan } \\
\text { kepada Pak Prabowo, bahwa } \\
\text { korupsi kita di tahun } 98 \text { itu, } \\
\text { negara kita terkorup di Asia, } \\
\text { indeks persepsi korupsi kita saat } \\
\text { itu adalah } 20 \text {, saya ingat betul. }\end{array}$ & $\begin{array}{l}\text { Representative } \\
\text { (Assertion) }\end{array}$ & Joko Widodo \\
\hline
\end{tabular}




\section{JLIC \\ Journal of Language Intelegence and Culture}

KPK mengatakan ini dua puluh, 2014 angka kita menjadi lebih baik menjadi 34 dan sekarang ini indeks persepsi kita 38 artinya, artinya ada perbaikan perbaikan terus.

(And I need to convey to Pak Prabowo, that our corruption in 1998, our country was the most corrupt in Asia, index perception of our corruption at that time was 20, I remember very well. The KPK said it's twenty, 2014 our figure has gotten better to 34 and now our perception index is 38 , it means that there is continuous improvement)

\begin{tabular}{lll}
\hline 23 & $\begin{array}{l}\text { Saya hanya mengatakan saya } \\
\text { pengalaman Pak di tentara. } \\
\text { (I just say I have experience in } \\
\text { the army, sir) }\end{array}$ & $\begin{array}{l}\text { Representative } \\
\text { (Statement of }\end{array}$ \\
\hline
\end{tabular}

2. Directive

\begin{tabular}{|c|c|c|c|}
\hline No & Statement & $\begin{array}{l}\text { Type of } \\
\text { illocutionary }\end{array}$ & Speaker \\
\hline 1 & $\begin{array}{l}\text { Jadi bagi saya, kita harus } \\
\text { tingkatkan pertama adalah } \\
\text { anggaran pertahanan, tapi untuk } \\
\text { itu kita harus membuat sistem. } \\
\text { (So for me, first we must increase } \\
\text { the defense budget, but we have } \\
\text { to create a system for that) }\end{array}$ & $\begin{array}{l}\text { Directive } \\
\text { (Recommend) }\end{array}$ & Prabowo \\
\hline 2 & $\begin{array}{l}\text { Saya juga telah memerintahkan } \\
\text { untuk gelar pasukan di empat } \\
\text { titik penting. Gelar pasukan } \\
\text { terintegrasi yaitu di Natuna } \\
\text { sebelah barat, kemudian di } \\
\text { Morotai sebelah timur, } \\
\text { kemudian di Saumlaki dekat } \\
\text { Masela itu di sebelah selatan dan } \\
\text { kemudian di Biak. } \\
\text { (I have also ordered for troop } \\
\text { titles at four significance points. } \\
\text { The integrated title troops is in } \\
\text { Natuna in the west, then in } \\
\text { Morotai in the east, then in } \\
\text { Saumlaki near Masela in the }\end{array}$ & Directive (Order) & Jokowi \\
\hline
\end{tabular}


south and then in Biak)

\begin{tabular}{|c|c|c|c|}
\hline \multicolumn{4}{|c|}{ 3. Commisive } \\
\hline No & Statement & $\begin{array}{l}\text { Type of } \\
\text { illocutionary }\end{array}$ & Speaker \\
\hline 1 & $\begin{array}{l}\text { Di bidang pertahanan keamanan } \\
\text { kita terlalu lemah, anggaran kita } \\
\text { terlalu kecil ini akan kita perbaiki } \\
\text { kemudian di bidang hubungan } \\
\text { internasional kita menganut } \\
\text { seribu kawan terlalu sedikit satu } \\
\text { lawan terlalu banyak. } \\
\text { (In defense and security, we are } \\
\text { too weak, our budget is too } \\
\text { small, and we will fix it later in } \\
\text { the field of international relations. } \\
\text { We have a thousand friends are } \\
\text { too little, one against is too } \\
\text { many) }\end{array}$ & Commisive (Offer) & Prabowo \\
\hline 2 & $\begin{array}{l}\text { Kita akan baik dengan semua } \\
\text { negara dengan semua kekuatan di } \\
\text { seluruh dunia kita akan baik kita } \\
\text { akan mencari hubungan yang } \\
\text { saling menguntungkan tapi juga } \\
\text { kita akan mempertahankan dan } \\
\text { membela rakyat kita yang utama. } \\
\text { (We will be good with all } \\
\text { countries with all powers around } \\
\text { the world we will be good we will } \\
\text { seek mutually beneficial relations } \\
\text { but also we will defend and } \\
\text { defend our people who are } \\
\text { foremost) }\end{array}$ & $\begin{array}{l}\text { Commisive } \\
\text { (guarantee) }\end{array}$ & Prabowo \\
\hline 3 & $\begin{array}{l}\text { Saya, kami berpendapat bahwa } \\
\text { kalau kami menerima mandat } \\
\text { kami akan membersihkan } \\
\text { lembaga-lembaga pemerintah, } \\
\text { kami akan memperkuat lembaga- } \\
\text { lembaga pemerintah, kami akan } \\
\text { perbaiki seluruh kehidupan } \\
\text { kualitas hidup seluruh aparat } \\
\text { pemerintah. Supaya kita akan } \\
\text { menghilangkan sekuat tenaga } \\
\text { korupsi yang ada di republik ini. } \\
\text { (I, we think that if we accept our } \\
\text { mandate to clean up government } \\
\text { institutions, we will strengthen } \\
\text { the government institutions, we } \\
\text { will improve the whole life quality }\end{array}$ & $\begin{array}{l}\text { Commisive } \\
\text { (promise) }\end{array}$ & Prabowo \\
\hline
\end{tabular}




\section{JLIC \\ Journal of Language Intelegence and Culture}

of all government officials. So that we will eliminate the corruption that exists in this republic as strong as possible the corruption in this republic)

\begin{tabular}{l}
\hline 4 Pada suatu saat apabila \\
pertumbuhan ekonomi kita \\
semakin baik, karena ekonomi \\
dunia juga pada posisi normal \\
kita akan bisa memberikan \\
anggaran yang lebih baik kepada \\
TNI kita, dalam rangka \\
membangun alutsista ke depan \\
yang lebih baik. \\
(At some point, if our economic \\
growth better, because the \\
economy in the world is also in a \\
normal position, we will be able \\
to provide a better budget to our \\
TNI, in order to build the better \\
defense equipment in the future)
\end{tabular}

4. Expressive

\begin{tabular}{|c|c|c|c|}
\hline No & Statement & $\begin{array}{l}\text { Type of } \\
\text { illocutionary }\end{array}$ & Speaker \\
\hline 1 & $\begin{array}{l}\text { yang saya cintai yang saya } \\
\text { banggakan seluruh rakyat } \\
\text { Indonesia di manapun berada } \\
\text { dari Sabang sampai Merauke dari } \\
\text { Miangas sampai pulau Rote yang } \\
\text { saya hormati Ketua KPU dan } \\
\text { Komisioner, Ketua Bawaslu dan } \\
\text { Komisioner yang saya hormati } \\
\text { sahabat baik saya Bapak Prabowo } \\
\text { Subianto, Bapak Sandiaga Uno. } \\
\text { (All of Indonesian from Sabang } \\
\text { to Merauke from Miangas to } \\
\text { Rote Island whom I love. The } \\
\text { Chairman of the KPU and the } \\
\text { Commissioner, the Chairman of } \\
\text { Bawaslu and the Commissioner } \\
\text { whom I respect. My good friend } \\
\text { Mr. Prabowo Subianto, Mr. } \\
\text { Sandiaga Uno whom I respect) }\end{array}$ & Expressive & Joko Widodo \\
\hline 2 & $\begin{array}{l}\text { Bapak Ibu sekalian yang saya } \\
\text { hormati } \\
\text { (Dear brothers and sisters) }\end{array}$ & & Joko Widodo \\
\hline
\end{tabular}


5. Declarative

\begin{tabular}{llll}
\hline No & Statement & $\begin{array}{l}\text { Type of } \\
\text { illocutionary }\end{array}$ & Speaker \\
\hline 1 & $\begin{array}{l}\text { Saudara sekalian di ruangan ini } \\
\text { saya Prabowo Subianto bersama } \\
\text { saudara Sandiaga Salahuddin }\end{array}$ & $\begin{array}{l}\text { Declarative } \\
\text { (Declare) }\end{array}$ & Prabowo \\
& Uno mendapat kepercayaan maju \\
& sebagai calon presiden dan calon & & \\
& wakil presiden. & \\
& (Ladies and gentlemen, in this & \\
room, I am Prabowo Subianto, \\
along with Sandiaga Salahuddin \\
Uno, declare as presidential and \\
vice presidential candidates)
\end{tabular}

As you can see from the analyzed data, not all the types are used. Further, based on the findings above, it can be stated that both of the candidates of president used representative, yet in other of illocutionary, they did not use it all. One of them used it, and one of them did not use it. After analyzing the data, it is found that Joko Widodo mostly used representative of fact and sssertion. It is caused since he is president in Indonesia. Therefore, he produced the utterances that contained fact and assertion. Meanwhile, Prabowo dominated his uttreance in commisive.

Moreover, based on the data analysis, the candidates of president mostly used representative of fact and assertion. They uttered the representative to show what they believe. In assertion, they wanted to show their assertiveness to the audience. In description, both of them just produced an utterance. Prabowo described about the corruption in this country, while Joko Widodo described Indonesia as the largest moslem country in the world. In directive types, Prabowo used recommend, whereas Joko Widodo used order to show his power as president. In commissive, Prabowo used offer, guarantee and promise. While Joko Widodo just used promise. He dominated expressive in his utterances. In this section, he wanted to show his thankfulness and his feeling in respect and love to people. Prabowo did not used this type of illocutionary act. He used declarative to declare himself that he and his partner would be a candidate of president. Joko Widodo did not use this one. 


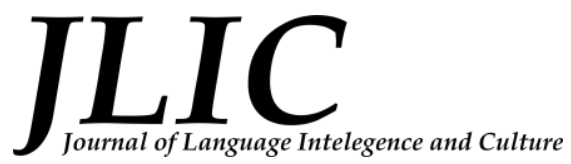

\section{CONCLUSION}

In some, it is concluded that both of candidates of president did not use five types of illocutionary act. They just used four of them in producing the illocutionary act. Prabowo just used representative, directive, commissive, and declarative. Joko Widodo used four types too, they are representative, directive, commisive, and expressive.

\section{REFERENCES}

Chaer, A. \& Agustina, L. 2004. Sosiolinguistik: Perkenalan Awal. Jakarta: PT. Rineka Cipta.

Yule, G. 1996. Pragmatic. Oxford University Press.

Cutting, Joan. 2008. Pragmatics and Discourse. New York: Routledge.

Austin, J.L. 1962. How to Do Things with Words. London: Oxford University Press.

Leech, Geoffrey. 1983. Principles of Pragmatics. New York: Longman Singapore Publishing.

Searle, John R. 1976. A Classification of Illocutionary Act. Cambridge: Cambridge University Press.

Mufiah, N.S \& Rahman, M.Y.N. 2018. Speech Act Analysis of Donald Trump's Speech. Professional Journal of English Education. Volume 1, No. 2, March 2018.

Widiatmoko, P. 2017. Analysis of Presidential Inaugural Addresses Using Searle's Taxonomy of Speech Act. English Review: Journal of English Education. Volume 5, Issue 2, June 2017.

Hajan, B.H, Hajan, B.C \& Ponesto, A.S. 2018. A Speech Act Analysis of the Last Two Post-Martial Law Philippine Presidents' First State of the Nation Addresses. Educativ: Journal of English Education and Teaching Innovation. Volume 2, No 2, December 2018.

Rijal, Samsi. 2016. Illocutionary and Perlocutionary Act on Madurese Language. Malang: UIN MALIKI Press. 